\title{
Implementation of an HIV \& AIDS Programme in South African Schools: Strengths and Weaknesses
}

\section{Linda van Rooyen* and Dirk van den Berg}

\author{
University of Pretoria
}

\begin{abstract}
The primary aim of this study was to explore the lived-experiences of teachers who were responsible for the presentation of the official HIV \& AIDS Programme of the Department of Education of South Africa. The study was motivated by the fact that it seemed as if schools do not implement the prescribed programmes as research has indicated that a mere $18 \%$ of schools are following a Sexuality Education Programme with HIV \& AIDS as a core component. Experts commonly hold the view that HIV infection can be prevented through education and positive changes in sexual behaviour. The spread and the rising incidence of HIV \& AIDS in South Africa are damaging our society and our education system. Many schools are already experiencing great difficulties, and school communities no longer depend on healthy learners, stable families, competent teachers or a strong economy.

The findings of this study indicated teachers' perceptions and experiences of the HIV \& AIDS programme. Although the implementation of HIV \& AIDS programmes in schools was made compulsory, the study indicated that schools were not adhering to this requirement, due to factors such as a lack of sound management practices in schools, insufficient training of teachers and school managers and uninvolved stakeholders.
\end{abstract}

In South Africa, the HIV \& AIDS epidemic ${ }^{1}$ has already reached the stage of "generalised infection" which implies that more than ${ }^{1}$ The concept "epidemic" means that the disease is spreading rapidly and extensively among many individuals in an area. The disease is prevalent in a community at a specific time. It breaks out in a place and lasts for a time only. The concept "pandemic" refers to a widespread, general or universal prevalence of a disease. The disease is endemic over the whole world it has a slow onset, and then causes a serious disruption of the functioning of society, resulting in widespread human disaster, and material and environmental loss - a massive silent and slow developing catastrophe (Van Rooyen 2001:7). With regard to "endemic" a disease is peculiar to and recurring in a particular locality (Reader's Digest Universal Dictionary 1989:509).

*To whom all correspondence should be addressed: Prof. Linda van Rooyen Faculty of Education, University of Pretoria, Groenkloof Campus, C/o Leyds and George Storrar Drive, Groenkloof, 0002 Pretoria, South Africa. E-Mail linda.vanrooyen@up.ac.za. Cell. +27 83288 5148. Tel. (office) +12 4203319. 
one percent of the population is infected with HIV \& AIDS and that the epidemic shows no signs of declining (UNAIDS, 2006, p. 17; Statistics South Africa, 2006, p. 4). In this regard a National HIV Survey revealed that approximately $11,1 \%$ of the total population (5.5 million people) were already living with HIV \& AIDS (Statistics South Africa, 2007, p. 2; UNAIDS, 2007, p. 9). More people are infected every three days in South Africa than the total number of deaths on 9/11 in New York.

The total number of children that are HIV infected in South Africa is estimated at 240000 (Department of Health, 2005, p. 64). The highest HIV infection rate in South Africa occurs among the age group 15-24 years. An estimated $18.8 \%$ of people between the ages of 15-49 years are currently living with HIV \& AIDS, while $70 \%$ of all deaths in this age group are ascribed to AIDS (Statistics South Africa, 2007, p. 2). In South Africa HIV \& AIDS will have killed two thirds of the adolescents that are currently 15 years old, by the year 2015 .

Experts commonly hold the view that HIV infection can be prevented through education and positive changes in sexual behaviour (Department of Education, 2000, p. 39; Kelly, Parker and Oyosi, 2002, p. 20; Badcock-Walters and Whiteside, 2003, p. 3; Department of Education, 2003d, p. 13). Even though a significant number of education programmes are being presented to young children and adults in schools and society in South Africa, research indicates that the HIV infection rate is increasing. Although prevention strategies have been in place since 2001 (UNAIDS, 2002b:47), the prevalence rate remains unacceptably high in South Africa, while research indicates that a mere $18 \%$ of schools are following a Sexuality Education programme with HIV and AIDS as a core component (Rademeyer, 2003, p. 2; Mathews, Boon, Flisher and Schaalma, 2006, p. 389).

The spread and the rising incidence of HIV and AIDS are damaging our society and our education system. Many schools are already experiencing great difficulties, and school communities no longer depend on healthy learners, stable families, competent teachers or a strong economy (Department of Education, 2005, p. 64). If the infection rate continues to escalate and the projected mortality rates, especially among young people (adolescents), become a reality, it may have further devastating long term consequences for South Africa.

In view of the specific nature and prevalence of the disease, we assumed that the current strategies for preventing the high rate of HIV and AIDS infection amongst the 15-24 year old age group are not successful, or are not successfully being implemented as far as school programmes are concerned. 


\section{MOTIVATION FOR THIS RESEARCH AND STATEMENT OF THE PROBLEM}

It is within this framework that the researchers were convinced that these facts are an outcome of one or more significant causes, especially if it is considered that a globally driven HIV and AIDS programme were developed and made compulsory for South African schools (World Bank, 2002, p. 17; UNESCO, 2004, p. 33). Which factors are responsible that the message does not reach the learners? Do SGB's, management teams and parents not consider the programme to be important? Don't they realise that it is a matter of life and death? What is done in schools regarding HIV and AIDS? What significance do teachers attach to the programme? The researchers decided to undertake a study with regard to the lived-experiences of teachers in order to provide answers to these questions and new knowledge that can contribute to the sound implementation of HIV \& AIDS programmes in schools.

With these questions in mind, the research problem of this study was formulated as follows: What are the lived-experiences of teachers with regard to the HIV \& AIDS programme in their schools?

\section{VALUE AND DELIMITATION OF THIS STUDY}

The value of this study lies in the fact that the results can provide insight into and promote understanding of the lived-experiences of teachers regarding the factors that influence the implementation of the HIV \& AIDS programme in schools. It could further inform policy developers with regard to shortcomings in the current HIV \& AIDS school policy. This study could also have significance regarding the improvement of teacher training in respect of the Life Orientation Learning Area and the delivery thereof. The research could also contribute to the improvement of curriculum delivery to learners and to mitigate the impact of HIV \& AIDS on the young people in South Africa.

This research will therefore mainly explore, describe and explain the lived-experiences of school management teams and teachers. This research will further be limited to the implementation of the official HIV \& AIDS programme of the Department of Education. 


\section{METHOD OF INVESTIGATION}

The researchers decided to conduct this investigation within the constructivist and interpretivist paradigms in order to construct their own understanding from the understanding with which the management teams and teachers construct their reality with regard to the implementation of the HIV \& AIDS programme. In accordance with the constructivist philosophy the researchers regarded this study, the school in society and the manner in which it succeeds in the implementation of HIV \& AIDS prevention programmes, as an important role-player within the multilayered reality of society (McMillan and Schumacher, 2001, p. 396).

In view of the aim of exploring, describing and explaining the lived-experiences of management teams and teachers, constructivism may provide a framework for interpreting and analysing the factors that negatively impact on the implementation efforts in schools (Sexton, 1997, p. 4). The researchers as interpretivists emphasize the permanence and priority of the real world of firstperson, subjective experiences of school management teams and teachers (Schwandt, 1998, p. 223).

Schwandt (1998, p.222) further clarifies the manner in which research is integrated within the constructivist and interpretivist paradigms. Constructivists and interpretivists presume that, to understand this world of meaning, it must be interpreted. The researchers therefore intended to clarify the process of meaning construction and shed light on what and how meanings are embodied in the language and actions of school management teams and teachers. For us, to prepare an interpretation would entail the construction of a reading of these meanings, in an attempt to shed light on the problem.

For this purpose we preferred to follow a qualitative research approach which, according to Ericson (1986, p.125), aims at gaining greater insight into man's situation. The qualitative approach may provide us with an opportunity to gain insight into the subjective experiences of management teams and teachers, and with sensitivity regarding the contexts in which people interact with each other. The qualitative approach places an emphasis on better understanding of human behaviour and experiences (Garbers, 1996, p.15) in a more multi-faceted way (Parker, Dalrymple and Durden, 2000, p.82).

We realised that we might identify unanticipated information by means of our qualitative research approach, since the discussion is not limited by predetermined closed questions. A qualitative approach may therefore provide us with vivid information 
with regard to the manner in which the management teams and teachers feel, think and act, as well as what they believe regarding the HIV \& AIDS programme in their schools.

For the purpose of this study we preferred to follow an instrumental case study design in order to obtain an in-depth description of the lived-experiences of our research participants.

We foresaw that the data in our case studies would be hybrid by nature, consisting of new and existing information (Mouton, 2001, p.149). We preferred this design, as it complements the exploratory and inductive approach and is consistent with the aim of identifying and investigating the experiences of school management teams and teachers with regard to the HIV \& AIDS programme. This design was selected with the main purpose of answering our research question, and in order to gain insight into the underlying issue, rather than the cases themselves (Bergen and While, 2000, p. 45; Stake, 2000, p. 438; Berg, 2001, p. 68; Cohen, Manion and Morrison, 2003, p. 183). Although we shall investigate selected cases, analyse their contexts, and describe their regular implementation activities in detail (Stake, 2000 , p. 439), these activities will merely serve a supportive role during which the actual research interest (primary question) can be explored.

In choosing an instrumental case study design, we relied on the advantage of not only understanding the important issues about our particular research, but also highlighting other critical issues at hand (Stake, 2000, p. 439). Further characteristics of an instrumental case study design that we found advantageous were that it will forced us to constantly reflect on and revise meanings and impressions that we gained. Although we acknowledge that generalization would be limited, we shall be able to provide detailed, in-depth information and material. Having taken cognisance of the challenges and limitations of an instrumental case study design, it was important for us to keep in mind that the purpose of the proposed study is to present the case, which is the lived-experiences of management teams and teachers with regard to the HIV \& AIDS programmes in their schools.

\section{Selection of participants}

One of the most important considerations was the selection of a reliable sample of literature and participants for this research. A sample population was selected by means of a convenience sampling technique. We thought it may be most informative 
to select expert or master teachers rather than a sample of all teachers (McMillan and Schumacher, 2001, p. 176). Convenience sampling is said to be the selection of information-rich cases for obtaining an in-depth understanding (Patton, 2002, p. 230). Three schools were conveniently selected for the purpose of this research because of their close proximity to the city. A number of twelve participants were selected from the conveniently selected schools. Two identified teachers in each school that have been trained as "Master Trainers" with reference to the presentation of the HIV \& AIDS programme, formed part of the sample population for this research. These "Master Trainers" were nominated teachers from secondary schools that had been trained by their respective School Districts with regard to HIV \& AIDS education. These teachers had attended a four-day training course regarding the HIV \& AIDS programme. It was expected that these teachers (Master Trainers) would then provide the same training to colleagues of their own schools as well as neighbouring schools in their cluster. The remaining participants will be the respective principal and members of the school management team (head of department for Human and Social Sciences) of each selected school.

These teachers were selected because of their special interest in the HIV \& AIDS programme in schools and the specialised training that they have received from the Gauteng Department of Education. These participants were chosen because we thought them to have specialised knowledge and information with regard to the HIV \& AIDS programme.

\section{Data collection}

In order to add depth and richness to the proposed research, we decided to use multiple data collection methods, which is, in itself is a process of crystallization that can be used to add and reflect different nuances to the gathered data (Janesick, 2000, p. 288). In the light of the qualitative paradigm and instrumental case study design, the following data collection methods were chosen to provide the most reliable responses and contribute to the quality of the data: conceptual analysis, analysis of primary and secondary sources, semi-structured interviews, reflective journals, field observations, and visual data collection. 


\section{Quality criteria}

To ensure the trustworthiness of this research we attended to aspects such as 'credibility', 'transferability', 'dependability', 'confirmability' and 'authenticity' in addition to the criteria of internal and external validity, reliability and objectivity.

\section{Ethical considerations}

Due to the social nature of this research, we were aware that we not only have a responsibility towards our profession in the search for knowledge and truth, but also towards the research participants (Strydom, 1998, p. 25; Cohen et al., 2003, p. 292). The manner in which we conducted our research aimed to preserve the dignity of the participants. This implied that we meticulously followed the ethical procedures of the University of Pretoria with regard to obtaining informed consent from the participants; ensuring their privacy, confidentiality and anonymity.

\section{IN-DEPTH STUDY}

The in-depth study consisted of a literature study and the conducting of interviews.

\section{Literature study}

During the literature study important background information regarding the problem under investigation, was yielded. It indicated that despite the introduction of compulsory HIV \& AIDS and Sexuality Education programmes, embedded in the Life Orientation Learning Area in South African schools, many schools fail to implement the policy or to deliver the compulsory prescribed programmes as required by the Ministry of Education. As mentioned research indicates that a mere $18 \%$ of schools are following a Sexuality Education programme with HIV \& AIDS as focal point, despite the fact that $60 \%$ of the schools in the study acknowledge that learners are at serious risk of becoming HIV \& AIDS infected (Rademeyer, 2003, p. 2; World Bank, 2002, p. 30; Kwazulu-Natal Department of Education and Culture, 2002, p. 2; Department of Education, 2003d, p. 22). 
At the launching of the macro plan for education in South Africa, called "Tirisano" (Working Together), the then Minister of Education, Professor Kader Asmal, highlighted nine priorities, amongst which HIV \& AIDS was prominent (Department of Education, 2001a, p. 7; Department of Education, 2003d, p. 7). The Tirisano document outlines the education sector's strategy to deal with the HIV \& AIDS epidemic in a three-pronged approach. The approach firstly embarks on an awareness, information and advocacy campaign; secondly, ensures the introduction of the HIV \& AIDS issue into the curriculum, and; thirdly, plans for the inclusion of other HIV \& AIDS related issues within the education system (Van den Berg, 2008, p. 60).

I was clear that education can no longer be "business as usual" (Coombe, 2000b, p. 1). Constructs at the heart of education such as 'curriculum development' and 'educational support services' had to change under the influence of political will and the prevailing effect of the HIV \& AIDS epidemic in South Africa. Van Rooyen (2001, p. 15) emphasizes the fact that society expects of the school to reduce the spread of the virus and to take up its responsibility in the fight for survival against the dreaded virus. It was obvious that prevention programmes could only be effective if they reach as many learners as possible. A collective view arose that utilizing educational structures and institutions might be the most logical (and cost-effective) way of getting prevention strategies across to adolescents in an effort to promote responsible sexual behaviour (Kelly, 2000, p. 14; World Bank, 2002, p. 3; Van Rooyen and Louw, 1994, p. 113; Department of Education, 2003d, p. 5; Van den Berg, 2008, p. 37).

The research has shown that the responsibilities and traditional role of the teacher, amid the challenges of a fast changing world and the immense impact that HIV \& AIDS has within the educational sector, necessitate that the role of the teacher will have to be much more diverse as stipulated by SAQA which outlines the seven roles of teachers.

The primary responsibility of the teacher with regard to Sexuality or HIV \& AIDS Education is to teach learners about safe sexual behaviour and the values consistent with healthy community life (Coombe, 2001b, p. 5). Furthermore, the National Education Policy Act (Act 27 of 1996) directs teachers to protect the rights of learners; provide education and opportunities to learners infected with HIV \& AIDS; provide learners with care and counselling; create a safe and secure environment in institutions of learning; apply infection control measures universally, regardless of any learner's HIV status; employ adequate wound management 
in the classroom, in the laboratory and on the sports field or playground, when a learner sustains an open, bleeding wound. Teachers should assist in mitigating the impact of HIV \& AIDS on those they teach and support; educate learners about their rights concerning their own bodies, to protect themselves against rape, violence, inappropriate sexual behaviour and contracting HIV \& AIDS; and present Life-skills Education on an ongoing basis, that embraces HIV \& AIDS education and promotes abstinence from sexual intercourse.

Fundamental practices should be evident in learning institutions to mitigate the long-term consequences of the HIV \& AIDS epidemic for learners (Coombe, 2001a, p. 15). Teachers should be conversant with HIV \& AIDS as a disease, the traumas associated with the HIV \& AIDS epidemic, the socio-economic context in which the epidemic reveals itself, and their roles and responsibilities for guarding and guiding children and young people. It is expected that teachers will be equipped with basic knowledge and appropriate counselling and caring skills.

Teachers must be able to create a learning institution that serves as a safe haven for all those who learn and teach there (Coombe, 2001a, p. 17; Department of Education, 2003d, p. 6). This implies zero tolerance for discrimination, violence or abuse, but a guarantee for the safety and security of all learners and teachers (Act 84 of 1996).

Effective management and sturdy education on the part of the school may produce future citizens with the ability to prove themselves as norm-dependent and conscientious adults who can face a vigorous, changing world in which some of the values of the past may be inappropriate tomorrow and even today (Van Rooyen and Hartell, 2001, p. 16). School management has to do more than "wearing red ribbons and distributing condoms".

Research made it clear that the responsibility of implementing any educational programmes ultimately rests with the management of the school. It was clear that the implications of HIV \& AIDS, with special reference to the impact thereof on the education sector, will have far-reaching implications for the management and implementation of HIV \& AIDS programmes. According to Van Rooyen and Hartell (2001, p. 5), many of the appalling implications may not be known yet, but one recognized implication that influences the school directly and demands the attention of educational leaders and principals, is that effective management and leadership with regard to HIV \& AIDS prevention is of paramount importance in every school. 


\section{Interviews}

The participants were only approached after the questions were decided upon. Each question was measured against criteria like the following; What is the aim with the question? Will the answer shed light on the problem? Can this question inhibit or embarrass the interviewed person, or cause resentment, or "put him on the spot"? Will this question stimulate a flow of information? Is the question clear or is it ambiguous? How can the informant be put at ease? How will the interview be managed that the balance between revelation and the withholding of information be maintained? How will verbal responses and non-verbal reactions be monitored?

It is evident that the interaction that takes place in an interview, is highly complex. The topic of this study made the interaction even more complex due to the sensitivity and personal nature thereof. The interviewees nevertheless have seemed to be at ease and willing to oblige, and provided an abundance of data related to the topic under investigation.

In order to create an opportunity for the participants to clarify their perceptions with regard to the role of education in HIV \& AIDS prevention, we asked the participants the following questions: "Does education have a role in prevention of HIV infection? How do you view the role that education has to fulfil in this regard?" This information could help us understand how important the participants regarded education in preventing HIV infection (refer to Table 1). We anticipated that the perceptions with regard to the importance (or unimportance) of education regarding HIV \& AIDS might be a prominent factor that influences HIV \& AIDS programmes in schools.

The twelve participants answered positively to the question whether education has a role to play with regard to the prevention of HIV \& AIDS. The participants' views with regard to the role of education in HIV \& AIDS prevention included the following aspects:

- The provision of knowledge and information to learners and parents about sexuality, sex and HIV \& AIDS.

- Assistance to parents who are unable to talk to their children about HIV \& AIDS because of cultural barriers.

- Support for learners who are infected or affected by HIV \& AIDS to care and/or cope with their situations.

- Creates an environment for establishing contact with vulnerable learners, for example orphans. 
One participant viewed the role of education with regard to prevention of HIV \& AIDS as minimal. The participant felt that the time allocated to the programme in schools was limited. The participant was of the opinion that more time was needed to reach the learners, and that teachers should be allocated who solely dealt with the HIV \& AIDS programme in schools.

Another participant strongly felt that all school programmes should convey the same prevention message ... "all teachers must sing the same song". The participant also stated that sexual relationships between teachers and learners were hindering prevention efforts and messages communicated through education.

It is interesting to note that all the participants regarded education as having an important role with regard to the prevention of HIV infection (as indicated in Table 1 above). This indicated that the participants might also regard the implementation of the HIV \& AIDS programme as equally important although the participants displayed little confidence in the impact of the programme has with regard to changing the behaviour of learners (as indicated in Table 2.)

We asked the opinion of the participants with regard to what they considered the impact of their school's HIV \& AIDS programme to be. The aim of this question was to determine the manner in which a participant viewed the impact of his/her school's HIV \& AIDS programme on the learners, in other words: Does the programme make a difference? We anticipated that this information would highlight the participants' perceptions of the value that their schools' HIV \& AIDS programme had for learners, in light of the fact that they considered education to have an important role to fulfil in the prevention of HIV \& AIDS.

In Table 2 nine participants reported that the HIV \& AIDS programme of their schools had a limited impact. Three participants reported that their school's programme had no impact. The participants' lack of confidence in the programme, can be ascribed to the fact that they only view and present HIV \& AIDS as a topic in the Life Orientation programme.

The participants shared the following personal views regarding the causes of the limited or no impact that the programme had, according to their lived-experiences and opinions (refer to Diagram 1 below):

Regarding this question, we concluded that the HIV \& AIDS programme, as implemented by the schools, seems to have little or no impact according to the lived-experiences of teachers 
TABLE 1

Participants' opinions on the role of education in the prevention of HIV \& AIDS

\begin{tabular}{|c|c|c|}
\hline Participant & $\begin{array}{l}\text { Does education } \\
\text { have a role in } \\
\text { prevention of } \\
\text { HIV infection? }\end{array}$ & $\begin{array}{l}\text { Participants' views with regard } \\
\text { to the role of education in } \\
\text { the prevention of HIV infection }\end{array}$ \\
\hline & YES & \\
\hline C1: P & $x$ & $\begin{array}{l}\text { Prevention through education can } \\
\text { work if learners are educated } \\
\text { and they "listen". Parents must } \\
\text { play a role in prevention efforts } \\
\text { and the same efforts must be } \\
\text { emphasised at school. The African } \\
\text { cultural taboos make it difficult } \\
\text { for the parents to talk about } \\
\text { sexuality. Parents must also be } \\
\text { educated to talk to their children } \\
\text { about sex and HIV \& AIDS. }\end{array}$ \\
\hline C2: P & $X$ & $\begin{array}{l}\text { Education must inform and } \\
\text { provide knowledge to learners } \\
\text { and parents that HIV \& AIDS is } \\
\text { a serious reality. }\end{array}$ \\
\hline C3: P & $X$ & $\begin{array}{l}\text { Education provides learners with } \\
\text { knowledge on HIV \& AIDS as the } \\
\text { parents are unable to do so. } \\
\text { Education also assists learners } \\
\text { who are infected or affected to } \\
\text { cope and care. }\end{array}$ \\
\hline C1: HOD & $X$ & $\begin{array}{l}\text { Prevention in education requires } \\
\text { the integration of all programmes, } \\
\text { and sending the same message } \\
\text { on prevention. "All must sing the } \\
\text { same song". Sexual relationships } \\
\text { between teachers and learners } \\
\text { make prevention difficult. The } \\
\text { morality of some teachers causes } \\
\text { prevention of fail. }\end{array}$ \\
\hline
\end{tabular}


C2: HOD

C3: HOD

C1: T1

C1: T2

C2: T1

C2: T2

C3: T1

C3: T2

Total
$X$

Education plays a minimal role because it only provides learners with information on HIV \& AIDS.

X Education is a way to make contact with vulnerable children. The school environment makes it possible to establish contact with learners.

X Education is a way to inform learners and the community about HIV \& AIDS.

X Education can help to impart knowledge and provide programmes in order to prevent HIV \& AIDS infection.

X Education provides learners with knowledge with regard to issues that parents are not discussing with them because their culture prohibits it. Education helps to overcome cultural barriers to information.

X Education provides learners with knowledge on preventing HIV \& AIDS as well as how to care for and to cope with those who are infected. Education provides an opportunity for learners who are affected by HIV \& AIDS to come to terms with their situations.

X Education must provide learners with knowledge on prevention by means of the Life Orientation programme.

X Education must make people aware of HIV \& AIDS. 
ธләчреәғ Чұ! ц!әчғ әлечs sıәuлеәт

7xoddns [етuәлеd oN

Клеssวzวu s! чрeordde

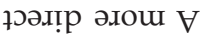

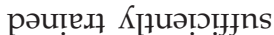
ұou s.วчวеәЈ

ssәидлеме uо sәsnวо

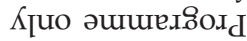

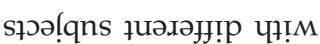

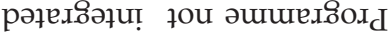

әвиечр ұоu

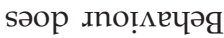

Xәs әfesun әлеч [I!ฺS s.дилеәТ

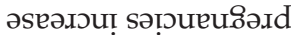

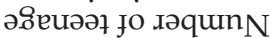

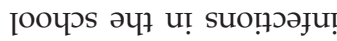
$\Lambda \mathrm{IH}$ MəU Киеи ло әлему

ఛoedui ou sеч әuाuexso.d ว૫.

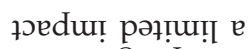

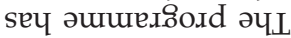

7oedum

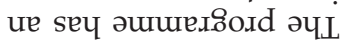

$\sigma \sigma \sigma \sigma \sigma \sigma \sigma \sigma \tau$

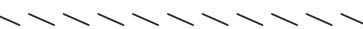

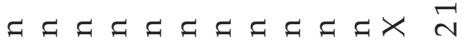

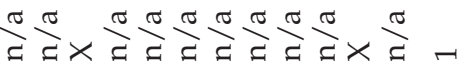

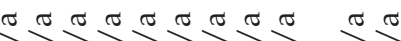

દ્વે વે વે વે

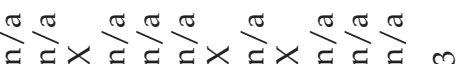

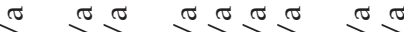

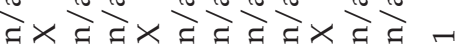

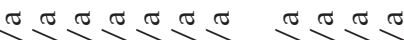

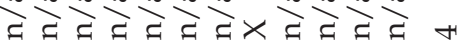

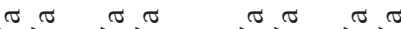

दे दे $\times$ दे $\times \times$ दे $\times$ दे

$\pi \sigma \tau \sigma \sigma \pi \sigma \tau$

द્ दे

$\pi \tau \pi \sigma \pi \sigma \pi$

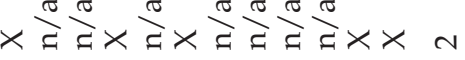

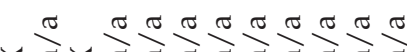

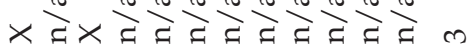

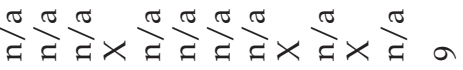

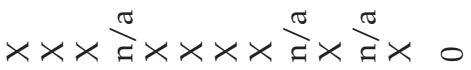

$\sigma \tau \sigma \tau \sigma \tau \sigma \tau \sigma \tau \sigma \tau$

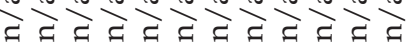

อิดิิิ)

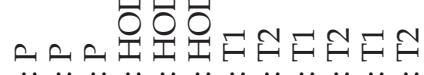

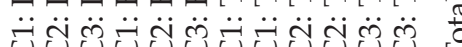




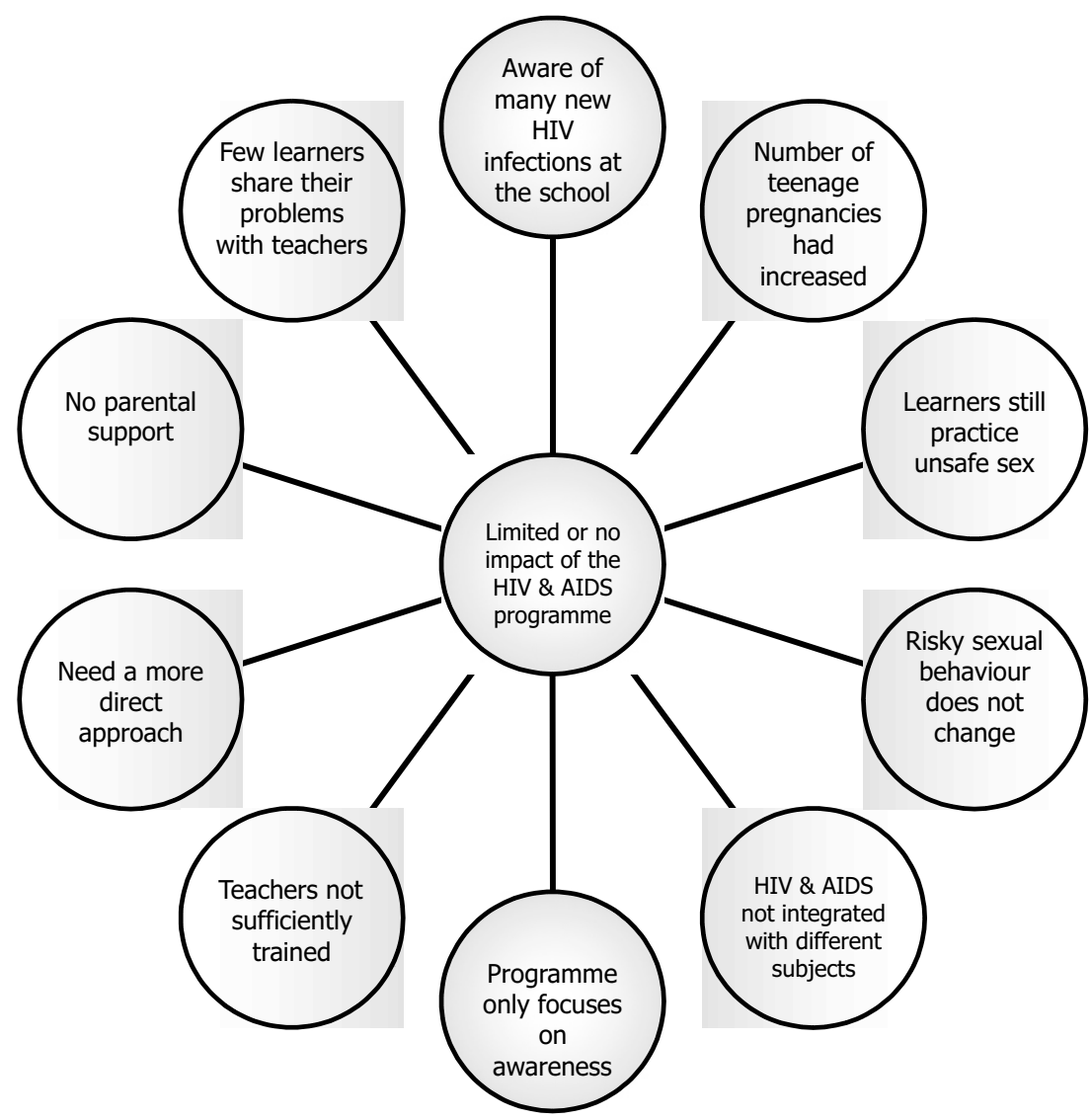

Diagram 1. Visual presentation of participants' opinions on the limited or no impact of $\mathrm{HiV} \&$ AIDS programmes

who present the programme. Even though the HIV \& AIDS programme is apparently presented, teachers experience that new HIV infections still occur; teenage pregnancies increase; learners still practise unsafe sex; risky sexual behaviour does not change; HIV \& AIDS is not integrated into all subjects; teachers are not sufficiently trained; and parental support with regard to the HIV \& AIDS programme is poor (Van den Berg, 2008, p. 186).

In light of the above responses we asked the participants: "According to you, what are the strengths and weaknesses of the implementation process followed by your school?", in order to investigate the participants' lived-experiences with regard to the implementation process of their schools. This information would provide us with insight into the manner in which the 
participants reflect on factors that influence the implementation of the HIV \& AIDS programme in their schools (refer to Table 3 for a summary of the responses).

Five participants affirmed that, regardless of weaknesses, their schools also had strengths with regard to the implementation of the HIV \& AIDS programme. The strengths included the availability of teachers to implement the programme; teachers who were eager to know more about HIV \& AIDS; although limited, some physical resources were available for facilitating the implementation of the HIV \& AIDS programme (Van den Berg, 2008, p. 214).

Seven participants stated that their schools lacked any strengths with regard to the implementation of the HIV \& AIDS programme. The mentioned weaknesses included factors such as the lack of an HIV \& AIDS school policy and/or policy procedures that teachers and learners were not aware of; the lack of seriousness with regard to dealing with HIV \& AIDS issues at schools; teachers who were inadequately trained and supported with regard to Life Orientation and HIV \& AIDS; the perception that dealing with HIV \& AIDS related topics was the responsibility of female teachers; an aversion amongst teachers in general to discuss HIV \& AIDS; the view amongst school management teams and teachers that the programme was less important than other programmes, because it is perceived not to be examinable; inadequate time allocation to Life Orientation, and inconsistent implementation of the HIV \& AIDS programme.

\section{CONCLUSON}

We concluded that, although some teachers (schools) have positive experiences with regard to the implementation of the HIV \& AIDS programme, the majority are burdened with curriculum management challenges, insufficient training of teachers, cultural taboos and uninformed and unsupportive colleagues.

The in-depth study provided valid fundamental and intimate information on the lived-experiences of school managers and teachers with regard to the HIV \& AIDS programme in their schools. During the interviews it became evident that managerial factors in the school as well as the perceptions and experiences of teachers with regard to the HIV \& AIDS programme, negatively influences the implementation thereof (refer to Diagram 2 on the next page). 

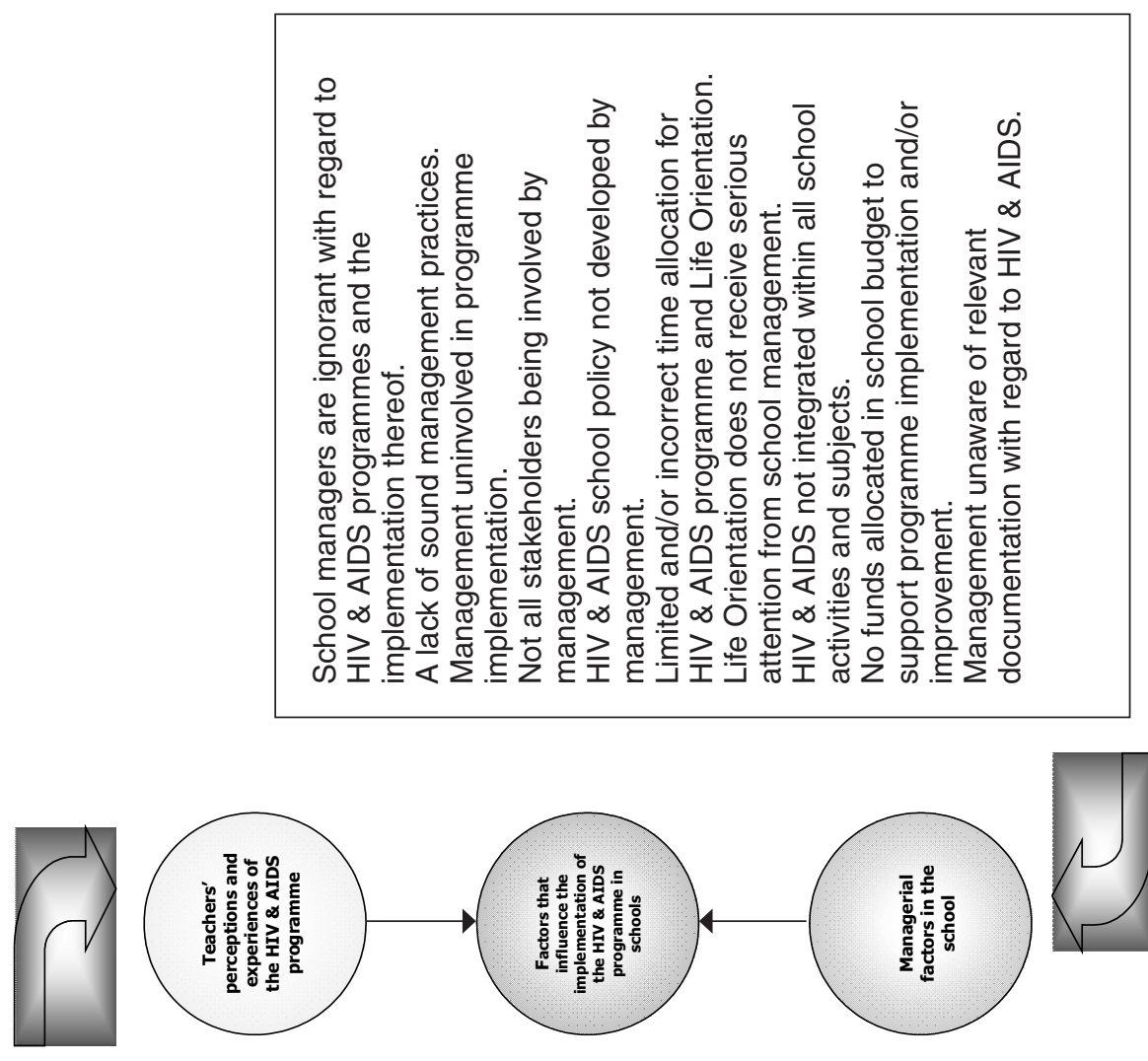

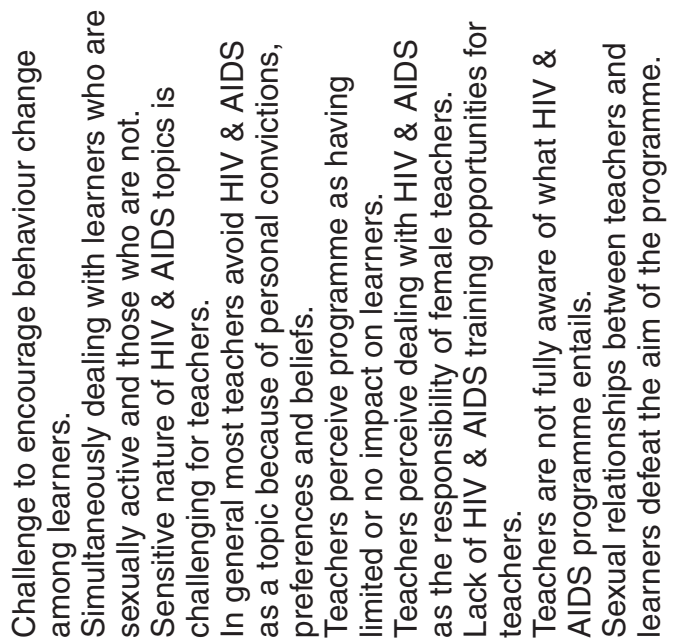

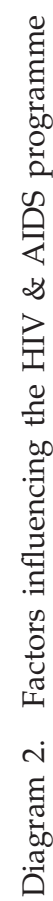


TABLE 3

Strengths and weaknesses in the schools' implementation of the HIV \& AIDS programme

Summary of Case Studies 1, 2 and 3

Participant The schools' implementation of the HIV \& AIDS programme

\begin{tabular}{|c|c|c|}
\hline & Strengths & Weaknesses \\
\hline C1: P & $\begin{array}{l}\text { Ability to educate learners } \\
\text { about HIV \& AIDS. } \\
\text { Encourage learners to } \\
\text { disclose their HIV status. }\end{array}$ & $\begin{array}{l}\text { Learners and teachers do not } \\
\text { know procedures in the HIV \& } \\
\text { AIDS policy. }\end{array}$ \\
\hline C1: HOD & No strengths mentioned. & $\begin{array}{l}\text { HIV \& AIDS is not taken } \\
\text { seriously enough at the school. }\end{array}$ \\
\hline C1: T1 & No strengths mentioned. & $\begin{array}{l}\text { HIV \& AIDS is not taken } \\
\text { seriously enough at the school. } \\
\text { The school has no policy and } \\
\text { no follow-up is done in } \\
\text { Life Orientation }\end{array}$ \\
\hline C1: T2 & $\begin{array}{l}\text { Teachers are eager to know } \\
\text { more about HIV \& AIDS. }\end{array}$ & $\begin{array}{l}\text { Teachers do not have enough } \\
\text { training with regard to HIV } \\
\text { \& AIDS. } \\
\text { No male teachers at school are } \\
\text { willing to discuss HIV \& AIDS. } \\
\text { Mainly see as the female teachers' } \\
\text { responsibility. Boys need male } \\
\text { teachers as role models who are } \\
\text { not afraid to discuss sex and } \\
\text { HIV \& AIDS. }\end{array}$ \\
\hline C2: P & No strengths mentioned. & $\begin{array}{l}\text { Most teachers are not interested } \\
\text { in discussing HIV \& AIDS. Not } \\
\text { enough time at the school to } \\
\text { implement the subject. } \\
\text { Learners have many subjects. }\end{array}$ \\
\hline C2: HOD & No strengths mentioned. & $\begin{array}{l}\text { HIV \& AIDS does not get } \\
\text { much attention. } \\
\text { The school management team } \\
\text { regard HIV \& AIDS and Life } \\
\text { Orientation as a waste of } \\
\text { time. Learners do not take it }\end{array}$ \\
\hline
\end{tabular}


C2: T1 No strengths mentioned.

C2: T2 No strengths mentioned.

C3: P School has human and physical resources available to address HIV \& AIDS issues.

C3: HOD Teachers are available to implement the HIV \& AIDS programme.

C3: T1 No strengths mentioned.

C3: T2 Teachers are available to implement the HIV \& AIDS programme. seriously.

HIV \& AIDS is not regarded as a serious issue at school. Management and teachers undermine Life Orientation because it is not an examination subject.

HIV \& AIDS and Life Orientation are not priorities.

School lacks consistency with regard to implementation of the HIV \& AIDS programme. Events happen periodically and are not emphasized enough.

Teachers are not adequately trained with regard to HIV \& AIDS and Life Orientation

Learners are ignorant with regard to HIV \& AIDS and do not take it seriously.

The school management team does not take Life Orientation and HIV \& AIDS seriously.

With regard to managerial factors we found that adequate provision is not made on school timetables, and suitable venues and teaching resources are not available. The research has further shown that a lack of sound management practices and lacking commitment restrain implementation efforts to such an extent that management ignore their responsibility regarding keeping abreast with relevant documentation and policy, and continue with business as usual, thereby neglecting the implementation of the HIV \& AIDS programme in totality.

Regarding the lived-experiences of teachers, they reported that they regarded the nature of the content of the HIV \& AIDS programme as too sensitive and too demanding to deal with in the classroom, for example, how to deal with sexually active learners, how to change their behaviour, and how to transcend personal convictions, beliefs and cultural taboos surrounding the topic of human sexuality. This can possibly be ascribed to a lack of proper training, and the fact that human sexuality forms an integral and personal part of being, and of constituting who I am. Teachers further reported a low level of confidence in the programme and view it as of limited impact. 


\section{REFERENCES}

Badcock-Walters, P. \& Whiteside, A. (2003). HIV \& AIDS and development in the Education Sector. USAID; Geneva.

Berg, B.L. (2001). Qualitative research methods for the Social Sciences. Allyn and Bacon; Needham Heights.

Bergen, A. \& While (2000). A case for case studies: Exploring the use of case study design in community nursing research. Journal of Advanced Nursing, 31(4): 1-14.

Cohen, L., Manion, L. \& Morrison, K. (2003). Research methods in Education. Routledge Falmer; New York.

Coombe, C. (2000b). Numbers and the AIDS effect. University of Pretoria; Pretoria.

Coombe, C. (2001a). HIV/AIDS and trauma among learners: sexual violence and deprivation in South Africa. University of Pretoria; Pretoria.

Coombe, C. (2001b). Mitigating the impact of HIV/AIDS on education supply, demand and quality: a global review. University of Pretoria; Pretoria.

Department of Education (2000). The HIV \& AIDS emergency: Department of Education's guidelines for Teachers. Department of Education; Pretoria.

Department of Education (2001a). Tirisano - working together. [Online] Available at: http: / /education.pwv.gov.za

Department of Education (2001a). HIV \& AIDS Resource Guides. Department of Education; Pretoria.

Department of Education (2005). National Curriculum Statements grades 10-12 (General) - Life Orientation Programme Guidelines. Department of Education; Pretoria.

Department of Health (2005). South Africa National HIV Prevalence, HIV Incidence, Behaviour and Communication Survey, 2005. Department of Health; Pretoria.

Ericson, F. (1986). Qualitative methods in research on teaching. In: Wittrock, M.D. (Ed.), Handbook of research on teaching. McMillian; New York.

Garbers, J.G. (Red.) (1996). Doeltreffende geesteswetenskaplike navorsing. Pretoria; J.L. van Schaik.

Janesick, V.J. (2000). The choreography of qualitative research design. In: Denzin, N.K. \& Lincoln, Y.S. (Eds.), The handbook of qualitative research. Sage Publications; California.

Kelly, K. (2000). Communicating for Action: a contextual evaluation of youth responses to HIV \& AIDS. Beyond Awareness Campaign. Department of Health; South Africa.

Kelly, K., Parker, W. \& Oyosi, S. (2002). Pathways to Action - HIV \& AIDS prevention, Children and Young People in South Africa. Cadre; Pretoria.

Kwazulu-Natal Department of Education and Culture. (2002). HIV \& AIDS Plan for Education. As Is report.

Mathews, C., Boon, H., Flisher, J. \& Schaalma, P. (2006). Factors associated with teachers' implementation of HIV \& AIDS education in secondary schools in Cape Town, South Africa. In: AIDS Care, 18(4): 388-397.

McMillan, J.H. \& Schumacher, S. (2001). Research in Education: A conceptual introduction. Longman; Harrisonburg.

Mouton, J. (2001). How to succeed in your Master's and Doctoral Studies - a South African guide and resource book. Van Schaik; Pretoria.

Parker, W., Dalrymple, L. \& Durden, E. (2000). Communication beyond AIDS awareness: A manual for South Africa. Department of Health; Aucklandpark.

Patton, M.Q. (2002). Qualitative research and evaluation methods. Sage Publications; California. 
Rademeyer, A. (2003). Schools ignore prescribed sexuality programmes. Johannesburg; Media24.

Reader's Digest Universal Dictionary (1989). Reader's Digest Association Limited; London.

Republic of South Africa (1996a). South African Schools Act, Act 84 of 1996. Government Gazette, 377 (17579). Government Printer; Cape Town.

Republic of South Africa (1996c). National Education Policy Act, Act 27 of 1996. Government Gazette, 370 (17118). Government Printer; Cape Town.

Schwandt, T.A. (1998). Constructivist, interpretivist approaches to human inquiry. In: Denzin, N.K. \& Lincoln, Y.S. (Eds.), The landscape of qualitative research: Theories and issues. Sage Publications; London.

Sexton, T.L. (1997).Constructivist thinking within the history of ideas: The challenge of a new paradigm. In: Sexton, T.L. \& Griffin, B.L. (Eds.) Constructivist thinking in counselling practice, research and training. New York; Teachers College Press.

Statistics South Africa (2006). Mortality and causes of death in South Africa, 2003 and 2004. Pretoria; Statistics South Africa.

Statistics South Africa (2007). Mid-year population estimates - 2007. Statistics South Africa; Pretoria.

Stake, R.E. (2000). Case studies. In: Denzin, N.K. and Lincoln, Y.S. (Eds), The handbook of qualitative research. Sage Publications; California.

Strydom, H. (1998). Ethical aspects of research in the caring professions. In: DE VOS, A.S. (Ed.), Research at grass roots - A primer for the caring professions. Van Schaik Publishers; Pretoria.

UNAIDS (2002b). Report on the global HIV/AIDS epidemic (June 2002). UNAIDS; Geneva.

UNAIDS. (2006). Report on the Global AIDS epidemic. UNAIDS.; Geneva.

UNAIDS. (2007). AIDS epidemic update - 2007. UNAIDS; Geneva.

UNESCO. (2004). UNESCO'S strategy for HIV \& AIDS prevention education. Paris; IIEP Publications.

Van den Berg, D.N. (2008). Contextual factors influencing the implementation of an HIV \& AIDS programme. Unpublished PhD dissertation. University of Pretoria; Pretoria.

Van Rooyen, L. (2001). Interpretation of relevant policies on HIV \& AIDS. University of Pretoria; Pretoria.

Van Rooyen, L., \& Hartell, C. (2001). HIV and Education - Beyond 2000. In: Calitz, L., Fugelstad, O.L. \& Lillejord, S. (Eds.), Leadership in Education. Heinemann; Cape Town.

Van Rooyen, L. \& Louw, N. (1994). Sexuality Education: a guide for teachers. J.L. van Schaik; Pretoria

World Bank (1999). Intensifying action against HIV \& AIDS in Africa: Responding to a development crisis. World Bank; Africa Region.

World Bank (2002). Education and HIV \& AIDS - a window of hope. Washington; The World Bank. 